\title{
LXVI. On the solar eclipse which is said to have been predicted by Thales
}

\section{Francis Baily Esq.}

To cite this article: Francis Baily Esq. (1811) LXVI. On the solar eclipse which is said to have been predicted by Thales, Philosophical Magazine Series 1, 38:163, 357-371, DOI: $10.1080 / 14786441108638666$

To link to this article: http://dx.doi.org/10.1080/14786441108638666

里 Published online: 27 Jul 2009.

Submit your article to this journal

Џll Article views: 2

Q View related articles 5 
known meaning of these marks in his Mineral Maps, which are so anxiously expected.

In examining the directions and dips of the Strata, it is hoped that $\mathrm{Mr}$. A. will be particularly careful to discriminate in all cases, between the folia or stratula of thick beds, or of unstratified masses (or their accidental parallel fissures), and the regular strata-seams or partings of the strata : which, it is thought, could not always have been done by $M$. De Luc, in his $2 \mathrm{~d}$ and $3 \mathrm{~d}$ volumes of Geological Travels in England, in so invariably stating the dip of the strata to be, to or from, and never across the numerous valleys and combes, he describes, as his theory of their formation requires.

LXVI. On the Solar Eclipse which is said to have been predicted by Thales. By Francis Baily, Esq.*

$\mathrm{T}$ HERE is probably no fact in ancient history that has given rise to so many cliscussions, and to such a variety of opinions, as the solar eclipse, which (according to Herodotus) is said to bave been predicted by Thales; and which, owing to a very singular coincidence, put an end to a furious war that raged between Cyaxares king of Media, and Alyattes king of Lydia.

According to the account given by that celebrated historian, "the contest had continued during five years, with alternate advantages to each party: in the sixth, there was a sort of nocturnal combat. For, after an equal fortune on both sides, and whilst the two armies were engaging, the day suddenly became night. Thales, the Milesian, had predicted this phænomenon to the Ionians; and had ascertained the time of the year in which it would happen. The Lydians and the Medes, seeing that the night had thus taken the place of the day, desisted from the combat; and both parties hecame desirous of making peace."

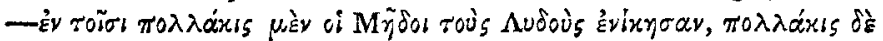

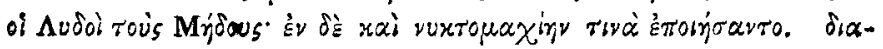

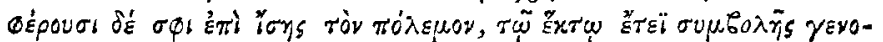

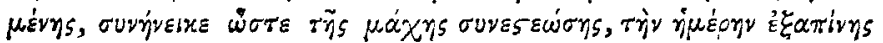

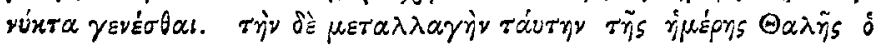

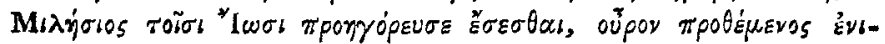

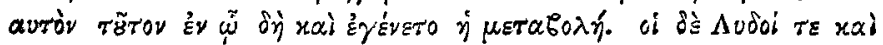

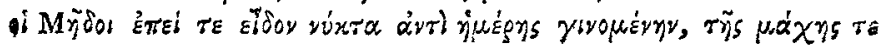

* From the Philosophical Transactione fur 1811, part ii. 


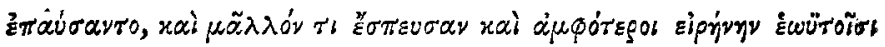

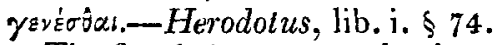

The fact is here very clearly (and probably very justly) related: but, unfortunately, there is nothing, either in the statement itself or in the contiguous passages of the work, that will enable us to determine, with any degree of accuracy, the exact time wherein this singular phanomenon tonk place. And this is the more to be regretted, because the dates of several other events, recorded by the same historian, might be more easily ascertained, if the ara of this eclipse were correctly known; but which are now involved in much obscurity.

Deprived of ail information from the body of the work itself, chronologists have called in the aid of astronomy to assist them in fixing the date of this remarkable appearance. For it must be evident, that if we could ascertain, by this mean, that in any solar eclipse, which happened about that period, the centre of the moon's shadow passed over the country bordering on the twa contesting empires where the battle was probably fought (for Herodotus has likewise omitted to mention the place where the action occurred), we may reasonably and very fairly conclude, that that eclipse only was the one alluded to by the historian.-In this attempt, iowever, a great diversity of opinion has arisen; the origin of which it may be useful and entertaining here to trace. But, in order to render my subsequent remarks the more intelligible, I shall previously state the various dates that have been assigned to this event by the several authors above alluded to.

Pliny places this eclipse in the fourth year of the fortyeighth olympiad; which answers to the year 585 B.C. (Hist. Nat. lib. ii, cap. 12.) A similar opinion has been advanced, among the ancients, by Cicero (De Divinat. lib. i. $\$ 49$ ), and probably by Eudemus (Clement. Alex. Strom. lib. i. p. 354). And, among the moderns, by Newton (Chron of Anc.King. amended), Riccioli(Chron. Refor. vol. i. p. 225), Desvignoles (Chronol. liv. iv. chap. 5, § 7, \&c.), and Brosses (Mém. de 'l'Acad, des Belles Lettres, tom. xxi.' Mém.p. 33.)

Scaliger, in two of his writings (Animad. ad Euseb.p.89,

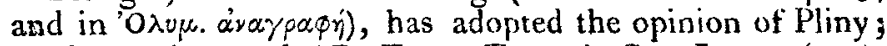
but in another work (De Emen. Temp. ine Can. Isag. p.'321), he fixes the date of this eclipse on the 1st of October, 583 B. C.

Calvisius, who was contemporary with Scaliger, thinks that it took place in the year 607 B. C. (Opus Chron.) 
Petavius says that it happened July 9, 597 B. C. (De Doct. Temp. lib. x. cap. 1): and he has been followed by Hárdouin Dissert. de lxx Heldom. Dan. § 3), Marshan (Chron. Canon. p. 561), Bouhier (Recher. et Diss. sur Hérodot.p. 42), and Corsini (Fast. Attiv. tom. iii. p. 68); together with M. Larcher, the French translator of Herodotus (tom. i. p. 335).

Usher is of opinion that it happened on the 20th of September, 6oi B. C. (Annal. Vet. et Nov. Testam.)

Bayer has shown, from the astronomical tables then in use, that this eclipse ought to have taken place May 18th, 603 B. C. (Com. Acad. Scient. Imp. Petrop tom. iii.): and he has been supported in this opinion by the two English astronomers, Costard and Stukeley. (Phil. Trans. for 1753, pages 17 and 221 .)

Lastly, M. Vnlney has attempted to show, in a recent publication (Chronologie d'Hérodote) that the eclipse, mentioned by the historian, could be no other than the one which happened February 3d, 626 B. C.

Thus we find a distance of no less than forty-three years between the extreme periods that have been assigned for this eclipse: an interval which, however, may be somewhat abridged; since there are other facts recorded by the same historian which enable us to reduce these limits, and yet leave the narration consistent with itself.

For, according to Herodotus, the two kings of Media, that immediately preceded the conquest of that country by Cyrus, were Cyaxares, who reigned forty years, and Astyages, who reigned thirty-five years: and it is admitted by all the chronologists, that Cyrus conquered Astyages in the year $560 \mathrm{~B}$. C. Consequently (if the numbers given by Herodotus be correct) the reign of Cyaxares extended from 635 B. C. to 95 B. C. And, since the battle of the eclipse was fought in the sixth year of a war which began after Cyaxares had ascended the throne, it could not happen earlier than 629 B. C. nor later than 595 B. C. If therefore we can find, within this short space of thirty-four years, a solar eclipse that was central and total in that part of Asia bordering on the two hustile empires, where this battle was probably fought, we may justly conclude that it was the one alluded to by the historian.

I say that this eclipse must have been a total one, because no annular eclipse (and much less a partial one) could have produced that degree of obscurity alluded to by Herodotus. The celebrated Maclaurin, in his account of the annular 
eclipse which happened at Edinburgh, February 18th, 1737, observes (Phil. Trans. vol. xl. p. 177), that "s during the " appearance of the annulus, the direct light of the sun was " still very considerable; but the places that were shaded from "c his light, appeared gloomy:"-that " day-light was not "greatly olscured; appearing only so much dimmer than " usual, as that of the sun is, when seen through a gentle "6 mist in a fine morning in April or May." And, as a further proof of the trifling alteration this phænomenon made, he observes, that "s there was little notice taken of this 'c eclipse by the populace in the country: and I cannot but « add, that several gentlemen of very good credit, and not in " the least short-sighted, assure me, that about the middle of " the annular appearance they were not able to discover the " moon upon the sun, when they looked without a smoked "6 glass, or something equivalent." In another account likewise of this eclipse, in the same volume, by sir John Clerk, bart. it is observed that there "was no considerable darkness; "but the ground was covered with a kind of dark-greenish "r colour." And M. Le Monnier (who came over from France on purpose to observe the annular eclipse of the sun, which happened July 14th, 1748) says, "sthat when be "6 looked at the sun with his naked eyes, during the middle " of the eclipse, he could observe nothing upon the sun, but "saw the sun full, though faint in his light." (Pbil. Trans. vol. xlv. p. 588.)

In the account also which is given, in the Mémoires de Z'Acad. Roy.des Sciences for 1724, of the total eclipse which happened on the $92 \mathrm{~d}$ of May in that year, it is stated that, at the moment when the last portion of the sun was covered by the moon, "la clarté a diminué tout d'un coup; de sorte " qu'on a eú besoin de lumière pour compter à la pendule: " on voyoit les personnes au grand air, mais on ne distinguoit " pas bien les visages à quelques pas de loin." In another account, in the same volume, it is stated, that the darkness came on "dans un instant;" and that, after an interval of two minutes and sixteen seconds, "le soleil commença à repa"roitre comme un éclair, qui dissipa sur le champ les tenèbres " dans lesquelles on étoit plongé." M. Desvignoles, likewise (in his Chronologie de l'Histoire Sainte, vol. ii. p.253), gives an extract of a letter from M. Abanzit of Geneva, who, at the close of his remarks on the calculation of $\mathrm{Pe}$ tavius respecting this very eclipse, observes; " il ignoroit "que le moindre raion, qui commence à poindre, est assez \$6 fort pour dissiper les tenèbres : comme je l' ai observé deux 
fois." All which may serve to explain the remarkable ex-

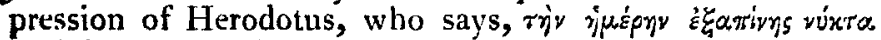
Yaviotal, "the day suddenly became night :" a passage which has been ignorantly censured by some of his commentators.

It appears to me, that an inattention to these singular facts has been the principal cause of the various opinions that have arisen respecting the time when this eclipse happened. For each chronologist, having a system of his own to support, has satisfied himself merely with ascertaining that a solar eclipse did take place in the year that he had assigned for it; and which eclipse be supposed might be yisible in that part of the world bordering on the two hostile countries : but without taking into bis account the magnitude of the eclipse at the place where the battle is sup. posed to have been fought. Now, since the territories of the two belligerent powers were probably separated by the river Halys (which was the case in the subsequent reign, although we have no authentic information that it was so at the period now under consideration), and as the battle was probably fought on the confines of these two empires, I think it will be evident from the preceding extracts, that no solar eclipse could be the one mentionerl by Herodotus, unless it was central and total in some part of Asia Minor; that is, the centre of the moon's shadow, in such total eclipse, must have passed over that part of Asia Minor where the contending armies were engaging. Consequently the fact is capable of being verified or disproved by the present state of our knowledge in astronomy.

M. Th. S. Bayer is the first who seems to have fixed the attention of the public to this point, in a paper entitled Chronologica Scythica, inserted in the Petersburg Memoirs for the year 1728. He consulted his friend Fred. Chris. Mayer on this subject, who has shown, from the astronomical tables then in use, that neither the eclipse mentioned by Pliny, Scaliger, Calvisius, Petavius, or Usher, could possibly be the eclipse alluded to by Herodotus. For, the first two (he says) happened between the hours of sun-set and sun-rise in Asia Minor. In the third, the centre of the moon's shadow passed too near the equator, and in the last two it passed too far to the north of Asia Minor, for it to cause any remarkable obscurity there. In order, however, to set the question at rest, he calculated all the solar eclipses that could possibly be seen in Asia Minor from the year 608 B. C. to $556 \mathrm{~B}$. C.; and he found that the one which took place May 18, 603 B. C. was the only one that 
was at all likely to be that mentioned by Herodotus. According to his computation, the centre of the moon's shadow in that eclipse entered the earth's disk about $N$. lat. $1^{\circ} 40^{\prime}$, and E. long. $23^{\circ}$ from Ferrol. It proceeded then towards the moutbs of the Nile; and, traversing the Mediterranean, crossed Cyprus, Cilicia, and Cappadocia, and passed over to Trebizond.

The rev. George Costard, without knowing what M. Mayer had done, has drawn nearly the same conclusions; and has likewise ęntered into a calculation (from Dr. Halley's tables) of all the eclipses which have been assigned to this event by preceding authors: which may be seen, at length, in the Philosophical Transactions for 1753. In a subsequent paper, in the same volume, Dr. Stukeley has given a map containing the path of the moon's shadow in this eclipse, deduced from the calculations of a Mr. Weaver; and which correspond nearly with Mr. Costard's. But Mr. Costard has suggested an important correction in his computation, by allowing for the moon's acceleration; which does not appear to have been attended to either by M. Mayer or Mr. Weaver: and which throws the route of the moon's shadow too far to the sonthward to pass over any part of Asia Minor. For, on this supposition (he observes) the umbra of the moon will leave Africa near Damietta; and, after traversing the south-east comer of the Mediterranean, will enter Syria between Tripoli and Tyre; and, proceeding across Mesopotamia, between Nisibin and Mosul, will enter the Caspian Sea near Ardebil. Notwithstanding this circumstance, however, the date here assigned has continued to be received as the true date of the battle of the eclipse by all succeeding chronologists; although it must he evident, even from these data, that such eclipse could not be total any where near the place where the battle was probably fought.

But none of these calculations cau bave much weight at the present day, since they must have been formed from tables which the subsequent improvements in astronomy have shown to be exceedingly defective and incorrect. Even the mean motions of the sun and moon are not'given with a sufficient degree of accuracy, either in the Rudolphine or Halleian tables, to enable us to determine, with any tolerable correctness, their true mean place of conjunction at so remote a period: neither can the lunar equations, there given, be safely depended upon. The secular variations also are wholly omitted: and these must have an important effect in all inquiries of this kind, since they increase in proportion to the period of time elapsed.

Under 
Under these circumstances, and in order to set this question at rest, as far as it can now be done by the aid of astronomical science, I have been induced to re-calculate the elements of the several eclipses, above alluded to, from the new Tales Astronomiques, lately published by the Bureau des Longitudes in France. In these tables, the mean motions of the sun and moon are given with the greatest exactness for the most distant periods : and, by the successive labours of Mayer, Mason, and Burg, the lunar equations are carried to an astonishing correctness; which, together with the secular variations deduced from the formula of M. Laplace, enable us to determine the true place of the sun and moon with considerable accuracy for many centuries prior to the Christian æra. These calculations, at full length, together with a map containing the paths of the moon's shadow in the several eclipses there alluded to, are sent with this paper for the inspection of the Members of the Royal Society, should they be desirous of entering more fully into the detail. The substance of those inquiries I shall now proceed to lay before them.

The eclipse, which is supposed to have been that alluded to by Pliny, happened May 28th, 585 B. C.: and the time of the ecliptic conjunction was at $2^{\text {h }} 38^{\prime} 22^{\prime \prime}$ in the afternoon, mean time at Greenwich, or $2^{\text {h }} 46^{\prime} 24^{\prime \prime}$ apparent time. The elements were as follow :

True longitude of the luminaries $1^{5} 29^{\circ} 41^{\prime} 4^{\prime \prime}$

Sun's declination, north ........ $2023 \quad 17$

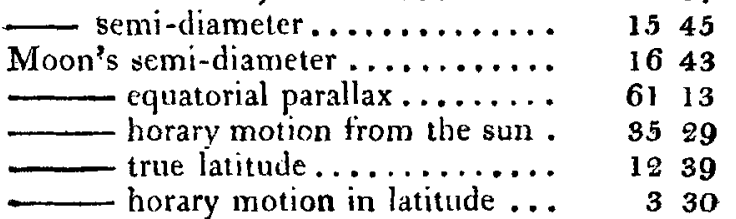

By a projection of this eclipse, I find that the sun was centrally eclipsed on the meridian, about the middle of the Atlantic ocean, in N. lat. $33 \frac{1}{4}^{\circ}$ and W. long. $43^{\circ}$. The centre of the moon's shadow then proceeded to the parallel of N. lat. $40^{\circ}$, in $W$. long. $13^{\circ}$; where, turning to the southward, it crossed Spain, and traversed the course of the Mediterranean. By a trigonometrical calculation I have ascertained that the sun set centrally eclipsed on the borders of the Red Sea in N. lat. $28^{\circ} 1^{\prime}$, and E. long. $35^{\circ} 2^{\prime}$. So that at no time was this eclipse central in or near any part of Asia Minor. It happened likewise ten years after the death of Cyaxares, according to the received chronology.

With respect to the eclipse which happened October 1st, 583 B.C. 
583 B. C. it is sufficient to observe that, as the ecliptic conjunction of the sun and moon did not take place till after four o'clock in the afternoon at Greenwich, it is evident that the sun must have set, centrally eclipsed, to the westward of any meridian line that can be drawn through any part of Asia Minor: and consequently the eclipse could not have been central in that peninsula.

Calvisius does not come much nearer the truth, in supposing that the eclipse mentioned by Herodotus is the one which occurred in 607 B. C. For in that which happened July $30 t h$, the ecliptic conjunction took place at $8^{\mathrm{h}} 26^{\prime} 18^{\prime \prime}$ in the morning, mean time at Greenwich, or $8^{\text {h }} 25^{\prime} 55^{\prime \prime} *$ apparent time: and the elements were as follow :

True longitude of the luminaries $3^{\text {s }} 29^{\circ} 6^{\prime} 54^{\prime \prime}$

Sun's declination, north .........20 $2038 \quad 39$

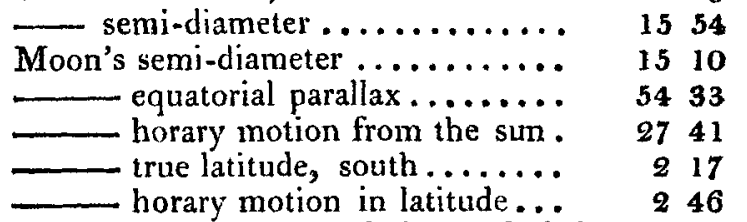

By a trigonometrical calculation, 1 find that the sun rose centrally eclipsed off the coast of Sierra Leona in N. lat. $8^{\circ}$ $13^{\prime}$ and $W$. long. $12^{\circ} 33^{\prime}$. The moon's umbra then crossed the continent of Africa between the 10th and 20th degrees of north latitude: and the sun became centrally eclipsed on the meridian in Arabia Felix, in N. lat. $181^{\circ}$ and E. long. $3^{\circ} 24^{\prime}$. It is evident, therefore, that this eclipse (independent of its being annular) was not central in any part of Asia Minor. The other eclipse in this year, which took place February $2 d$, happened when it was near midnight in Asia Minor.

The eclipse mentioned by Petavius took place July 9th, 597 B. C. The ecliptic conjunction happened at $4^{\mathrm{h}} 29^{\prime} 25^{\prime \prime}$ in the morning, mean time at Greenwich, or $4^{\text {h }} 29^{\prime} 58^{\prime \prime}$ appurent time: and the elements were as follow :

True longitude of the luminaries $3^{s} 9^{\circ} 16^{\prime} 32^{\prime \prime}$

Sun's declination, north......... $23 \quad 2818$

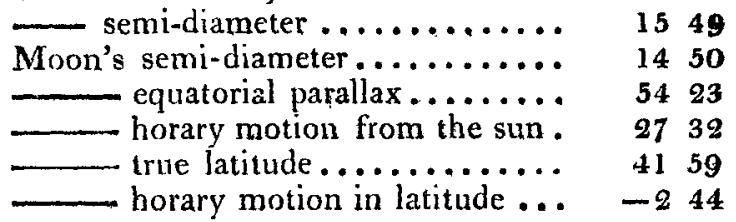

* [n the Phil. Trans. it is $8 \mathrm{~h} 35^{\prime} 45^{\prime \prime}$ : but we have the authority of the writer of this paper to make the above correction. -ED.] 
By a trigonometrical calculation, I find that the sun rose centrally eclipsed to the inhabitants of Holland in N. lat. $51^{\circ} 45^{\prime}$ and E. long. $5^{\circ} 39^{\prime}$. The moon's umbra then proceeded across Denmark, Finland, and the northern provinces of Russia : and the sun became centrally eclipsed on the meridian in N. lat. $74 \frac{1}{2}^{\circ}$ and E. long. $113^{\circ} 35^{\prime}$. This eclipse, therefore, could not possibly be the one mentioned by Herodotus. And yet his translator, M. Larcher, without taking the slightest pains to verify the fact, or even to ascertain its probability, has adopted it as the most likely one, " parcequ'elle s'accorde mieux avec la chronologie que " toutes les autres :" an opinion as unfounded, as the circumstance to which it relates; and an assumption which puts the visionary speculations of the antiquarian in competition with the immutable laws of nature. It is scarcely necessary to add, that this eclipse likewise was annular.

In the eclipse alluded to by Usher, September 20th, 601 B. C. the ecliptic conjunction took place at $7^{\mathrm{h}} 25^{\prime} 18^{\prime \prime}$ in the morning, mean time at Greenwich, or $7^{\mathrm{b}} 31^{\prime} 35^{\prime \prime} a p$ parent time: and the elements were as follow:

True longitude of the luminaries $5^{\mathrm{s}} 20^{\circ} 46^{\prime} 50^{\prime \prime}$

Sun's declination, north ........ $342 \quad 27$

- semi-diameter............ $16 \quad 8$

Moon's semi-diameter.......... 1643

- equatorial parallax........ 6114

- horary motion from the sun. $\quad 3524$

- true latitude ........... 52 1 horary motion in latitude... -327

From a projection of this eclipse, it will be seen that the centre of the moon's shadow entered the earth's disk very near the north pole; and that the sun became centrally eclipsed on the meridian in N. lat. $73 \frac{3}{4}^{\circ}$ and in E. long. $72^{\circ}$ 10'. The umbra then passed over Siberia and the eastern parts of the Chinese empire : and consequently this eclipse was not central in any part of Asia Minor.

The eclipse first suggested by Bayer, and hitherto generally received as the true one, happened May 18 th, $603 \mathrm{~B}$. C. The ecliptic conjunction took place at $7^{\mathrm{h}} 12^{\prime} 13^{\prime \prime}$ in the morning, mean time at Greenwich, or $7^{\mathrm{h}} 19^{\prime} 36^{\prime \prime}$ apparent time: and the elements were as follow:

True longitude of the luminaries $1^{\mathrm{s}} 19^{\circ} 15^{\prime} 44^{\prime \prime}$

Sun's declination, north $\ldots \ldots \ldots \ldots 1748 \quad 24$

- semi-diameter............ 1546

Moon's semi-diameter.......... $16 \quad 43$ equatorial parallax......... 6116 
Moon's horary motion from the sun . $35^{\prime} 32^{\prime \prime}$ true latitude .............

1715 horary motion in latitude ...

330

By a trigonometrical calculation, I find that the sun rose centrally eclipsed in S. lat. $5^{\circ} 9^{\prime}$ and E. long. $0^{\circ} 46^{\prime}$. The moon's umbra then passed over the continent of Africa in a north-easterly direction; and, crossing the Red Sea, entered Arabia near Mecca, continuing its course over the provinces of Kerman and Segistan in Persia. The sun afterwards became centrally eclipsed on the meridian in $N$. lat. $35_{\frac{1}{4}}^{\circ}$ and E. long. $68^{\circ}$. Consequently this eclipse could not be central in any part of Asia Minor : and yet it has generally been considered, of late years, as the only one that could be reconciled to the fact.

Lastly, I shall notice the eclipse proposed by M. Volney, which happened February $3 \mathrm{~d}, 626 \mathrm{~B}$. C. The ecliptic conjunction took place at $4^{\mathrm{h}} 19^{\prime} 27^{\prime \prime}$ in the morning, mean time at Greenwich, or $4^{\mathrm{h}} 0^{\prime} 35^{\prime \prime}$ apparent time: and the elements were as follow :

True longitude of the luminaries $10^{s} 7^{\circ} 47^{\prime} 47^{\prime \prime}$

Sun's declination, south......... $18 \quad 3550$

- semi-diameter ............ $16 \quad 7$

Moon's semi-diameter........... $\quad 15 \quad 16$

- equatorial parallax......... $55 \quad 56$

- horary motion from the sun. $\quad 2913$

- true latitude........... 4428 - horary motion in latitude... $\quad-253$

By a trigonometrical calculation, I have ascertained that the sun rose centrally eclipsed to the inhabitants of Great Buccharia in N. lat. $40^{\circ} 17^{\prime}$, and E. long. $61^{\circ} 35^{\prime}$ : and the moon's umbra then proceeded in a south-easterly direction across Thibet and China. Consequently this eclipse (which, moreover, was an annular one) could not possibly be central in any part of Asia lying to the west of the Caspian Sea: and M. Volney ought to have taken some steps towards ascertaining this fact, before he ventured to set up his own opinion in opposition to all preceding chronologists.

I have thus shown, from the most correct evidence which the present state of astronomical science affords, that not one of the eclipses, mentioned by either of the authors above alluded to, could possibly be that which is recorded in so singular a manner by Herodotus. In order, however, that I might not leave the subject in the same degree of doubt in which I found it, I have taken the pains to calculate all the solar eclipses that were likely to have been visible in 
Asia Minor, from the year 650 B. C. to 580 B. C.: but, out of this period of seventy years, I have found only one that was central in, or near, any part of that peninsula.

The eclipse here alluded to, happened September 3oth, 610 B. C. The ecliptic conjunction took place at $8^{\text {h }} 12^{\prime}$ $51^{\prime \prime}$ in the morning, mean time at Greenwich, or $8^{\mathrm{h}} 2 \mathrm{l}^{\prime} 4 \mathrm{l}^{\prime \prime}$ apparent time: and the elements were as follow :

True longitude of the luminaries $5^{\mathrm{s}} 29^{\circ} 59^{\prime} 40^{\prime \prime}$

Sun's declination, north ......... o 8

- semi-diameter............ 1610

Moon's semi-diameter ............ $16 \quad 1636$

- equatorial parallax........ $60 \quad 50$

- horary motion from the sun. $\quad 3453$

- true latitude.......... 2957 horary motion in latitude... 326

Since the sun's declination in this eclipse was only eight seconds, it may safely be neglected in the calculation; and it may then be found very easily by plane trigonometry that the sun rose centrally eclipsed in $N$. Jat. $47^{\circ} 34^{\prime}$, and $W$. long. $11^{\circ} 55^{\prime}$; that it was centrally eclipsed on the meridian in N. lat. $31^{\circ} 6^{\prime}$, and E. long. $59^{\circ} 33^{\prime}$; and set centrally eclipsed in N. lat. $11^{\circ} 13^{\prime}$, and E. long. $122^{\circ} 36^{\prime}$. The centre of the moon's shadow crossed the parallel of $\mathrm{N}$. lat. $42^{\circ}$ in $\mathrm{E}$. long. $34^{\circ} 45^{\prime}$; and the parallel of $\mathrm{N}$. lat. $36^{\circ}$ in E. long. $50^{\circ}$; and consequently passed nearly in a straight line over the north-eastern part of Asia Minor, through Armenia and Persia, where the sun became centrally eclipsed on the meridian, as above mentioned. This eclipse, therefore, was central and total to part of Asia Minor, Armenia, and Media : and the path of the moon's umbra lay in the very track where the two hostile armies probably met. For it passed over the very mouth of the Halys, just at the point where Croesus, the immediate successor of Alyattes, crossed that river in order to attack the Median empire.

It would appear from the order of events belonging to the reign of Cyaxares, as related by Herodotus, that the battle of the eclipse happened prior to the invasion of the Scythians, who kept possession of his kingdom twenty-eight years; and that, after the expulsion of those barbarians, he besieged and took the city of Nineveh, and thereby put an end to the Assyrian empire. This, however, will not accord with the date here assigned : neither indeed will it surt any of the systems above alluded to ; except it be that of $M$. Volney, which may lay claim to some ingenuity. But his 
system is too much at variance with the astronomical fact to be ontitled to any credit.

It has been remarked by Dr. Halley (Phil. Trans. vol. xxix. p. 245), that "though twenty-eight eclipses of the "sun happen in eighteen years, and eight pass through the "parallel of London, yet since March 20th, 1140, no total "eclipse has been seen in that metropolis." Indeed, so rare is this phænomenon in any particular country, that its occurrence, when well authenticated, may be considered as an zra which is less liable to mistakes or confusion, than any other event recorded in history. All attempts at imposition or deceit are easily detected by our knowledge of astronomy : and the unintentional errors of the historian are soon rectified and adjusted. On this account, and as the fact of the eclipse is so confidently related by Herodotus (indeed, its singular coincidence with the battle will ever render it memorable in history), I would place the termination of the war between Alyattes and Cyaxares, in the year 610 B.C.: and, if the other events of that period, as related by the historian, cannot be reconciled to this date, I should attribute the confusion to the want of authentic documents and information at the time that the history was written.

I have before observed, that all these calculations have been made from the Tables Astronomiques, lately published in France: which tables have since been adapted to the meridian of Greenwich, and to astronomical time, by $\mathrm{Mr}$. Vince, and inserted by him in the third volume of his System of Astronomy*. In these tables are given the secular variations in the moon's mean longitude, mean anomaly, and mean distance from her node, as deduced from the formula of M. Laplace. It is with much deference that 1 presume to question the accuracy of the results obtained by means of those formula; but, as the present subject is in a great measure connected with that inquiry, I shall briefly state my reasons for offering a doubt upon that point.

* It is to be regretted, that Mr. Vince did not adapt his tables to the Eng* lish system of chronology likewise. For the years betore Christ, according to the English mode of computation, exceed by unity the coresponding years given by the French chronologists: since they make the year of Christ equal to 0, whereas the English reckon it as 1 B. C.-The French also assume the year 1582 as the date of the reformation of the calendar; whereas, in Eng. land, that event did not take place till the year 1752.

Without a proper attention to these circumstances, we may be led into an error of one whole year, in the calculation of the places of the heavenly bodies for any period prior to the Christian zra; and into an error of ten or eleven days in our calculations for that space of time which is included between Oxtober 5th, 1582, and September $14 t h, 1752$. 
It is well known that Agathocles, king of Syracuse (when besieged in that city by Hamilcar the Carthaginian general), undertook the bold design of invading Africa, and thereby moving the seat of war from Sicily. He accordingly embarked a numerous army, and set sail for the continent. The day after he left Syracuse, the fleet was terrified at an eclipse of the sun; which was so great, that, in the words

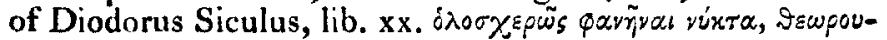

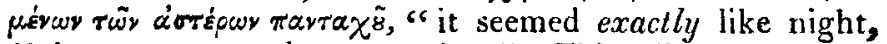
" the stars every where appearing." This eclipse was therefore evidenty total in the place where it was seen by the fleet of Agathocles. It happened on August 15th, 310 B. C. The ecliptic conjunction took place at $8^{\text {h }} 10^{\prime} 23^{\prime \prime}$ in the morning, mean time at Greenwich, or $8^{\mathrm{h}} 9^{\prime} 6^{\prime \prime} a p-$ parent time: and the elements were as follow :

True longitude of the luminaries $4^{\mathrm{s}} 16^{\circ} 41^{\prime} 32^{\prime \prime}$

Sun's declination, north .......... $16 \quad 238$

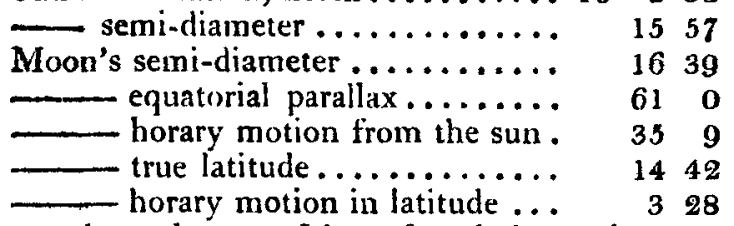

From these elements I have found, by a trigonometrical calculation, that the sun rose centrally eclipsed to the inhabitants of the western coast of Africa, in N. lat. $24^{\circ} 57^{\prime}$ and W. long. $14^{\circ} 9^{\prime}$. The centre of the moon's shadow then, crossing the Desert, proceeded towards the Mediterranean, near to, but rather to the southward of, Tripoli; and crossed the parallel of N. lat. $33^{\circ}$ in E. long. $20^{\circ} 44^{\prime}$. But in no part of its course did it advance more northerly than $N$. lat. $33^{\circ} 55^{\prime} 36^{\prime \prime}$, which I find by a trigonometrical calculation to be its maximum of latitude, and the parallel of which it reached in E. long. $35^{\circ} 21^{\prime} 8^{\prime \prime}$. It then turned to the south; and the sun became centrally eclipsed on the meridian in N. lat. $304^{\circ}$ and E. long. $59^{\circ} 45^{\prime}$.

Let us now compare this result, with the fact as related by Diodorus. It is stated by this author, that Agathocles was six days on his passage, from Syracuse to the coast of Africa; although he used the utmost expedition, being, in fact, closely pursued by the Carthaginian fleet. The place where he landed was called Narouias, the Quarries; whence

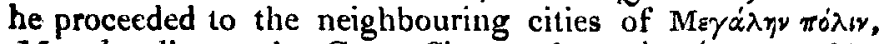
Megalopolis, or the Great City, and $\Lambda$ suxòr Túv Tunis. The position of these cities is not handed down to us; all that we know is, that the latter place (which must

Vol, 38. No, 163. Nov, 1811 .

A a

not 
not be confounded with the present Tunis) was two thousand stadia, or two hundred and twenty-nine English miles, distant from Carthage. Agathocles, therefore, probably landed near the Syrtis Minor, or Gulf of Cabes, ,about three hundred miles in a direct course from Syracuse: whence we may reasonablv conclude that he performed one-sixth of his passage, or about fifty miles, in the space of one day; which, I am aware, is not so much as the mean rate that has been attributed to the ships of the ancients (see Herodotus, lib. 4, $\$ 86$ ). Syracuse lies in N. lat. $37^{\circ} 3^{\prime}$ and $\mathbf{E}$. long. $15^{\circ} 14^{\prime}$; and, consequently, on the day after the sailing of Agathocles from that port (being the day on which the eclipse took place), the fleet would be in about N. lat. $36 \frac{1}{4}^{\circ}$ : at all events, it could not (from the direction of its course) be much further south than this point; which is all that is required in the present instance; and a few miles, either way, not being of any material consequence. It follows therefore, that in the meridian of Syracuse, the northern part of the moon's umbra ought to extend as far north as that parallel of latitude. But, from the calculations above adduced, it will be found that the centre of the moon's sbadow, on that meridian, had only reached the parallel of about $\mathrm{N}$. lat. $32 \frac{1}{2}$ : and as the semi-diameter of the umbra was not more than forty-seven and a quarter English statute miles, or about two-thirds of a degree, the eclipse could not there be total to the northward of $\mathbf{N}$. lat. 33 $\frac{1}{4}^{\circ}$. Now, since the place where Agathocles landed in Africa was probably not situated below the parallel of $\mathbf{N}$. lat. $34^{\circ}$, it is evident that he did not, in any part of his course (and much less at the commencement of it), come within a considerable distance of the moon's umbra.

I much doubt whether, according to our present computation, this eclipse was total even at Tripoli: and, although it was unquestionably of considerable magnitude, both there and as far north as Syracuse itself, yet (for the reasons already given in this paper) I do not think that, at any intermediate place between these two cities, it could be so great as to produce that degree of obscurity; which is recorded by Diodorus and confirmed by Justin. In order that the phanomenon should accord with the fact, as related by these historians, the centre of the moon's shador ought to pass over, or very near to, Malta : that is, the latitude of the rnoon ought to be, at least, three degrees greater than our present tables make it.

Since the latitude of the moon depends on her true distance from the node, these observations (if carrect), will 
show the necessity of some alteration in the table of the secular variation of the moon's mean distance from her node, which (agreeably to the rule given by $M$. Laplace) is deduced immediately from the secular variation of ber mean longitude. These remarks, however, are thrown out merely as hints to those who are more conversant with, and better informed on, the subject: and I regret that I have not more time to pursue the inquiry further.

Such an alteration, as is here suggested, would somewhat vary the position of the route of the moon's umbra, in all the eclipses which have been the subject of this paper; but, in none of them would it alter the conclusions which have been drawn from them, except perhaps in the one (September 30 th, 610 B. C.) which I have supposed to be that mentioned by Herodotus. In this particular case, the path of the moon's umbra might, by such a correction, be thrown so much further north as to prevent the eclipse being total in any part of Asia Minor. But still it would remain the only one that can be at alb adapted to the account given by Herodotus; since there is no other that could possibly be central in, or near, any part of Asia Minor from the year $650 \mathrm{~B}$. C. to $580 \mathrm{~B}$. C.: a period which far exceeds the probable limits of time wherein this singular phanomenon must have taken place, so as to be reconcileable to any received system of chronology.

November 1810.

F. B.

\section{An Account of the Smelting of Lead. By Mr. John Sadler.}

\section{[Concluded from p. 282.]}

\section{I} TE substances which are found to render the ores of lead refractory, when mixed with them, are cawk, (sulphate of barytes,) black jack, (blend or sulphuret of zinc,) sulphur, (iron pyrites,) and silver, or copper, when they are contained in the ore in larger proportions than usual.

I have always considered that these substances render an ore refractory by the extra quantity of sulphur they bring with them. I do not think the earth or metals alone would produce any visible effect in the smelting; and I am almost confirmed in this opinion, by repeatedly observing the effect produced by roasting the ore previous to smelting; it works more pleasantly, requires less lime and fuel, and gives a better produce.

The quality of the coals materially affects the working of A a 2 